\title{
Tourism Contribution to Dubai Economic Growth
}

\author{
Sadun N Yassin Alheety, Tariq Khalaf Barakat Ayoub
}

\begin{abstract}
Globally people have been trying to improve their living standards by inventing resources that are suitable for them while keeping their culture intact. It has been noticed that tourism as a growing industry could be one of the most important targets to achieve better economy and, more importantly, sustainable economy. The positive development of tourism in developed countries was taken by many developing countries and implementation of tourism was possibly a very important sector to the economy. In Dubai, the oil produced country, tourism is not a very old tradition; it is rather a new phenomenon that this study was found a very interesting topic to pursue and investigate. By setting the conceptual model, both variables, dependent and independent, were explored and studied using quantitative analysis by providing a suitable questionnaire hoping to explore a clear insight in both: the economy and the way people of Dubai thinking about tourism. Three independent variables of quality, assortment, and promotion were selected to see their impact on economic growth (dependent variable) in Dubai. A population of little more than 400 respondents was given a questionnaire that well-prepared to serve three hypotheses that are related to each of the impendent variables. The findings have shown that there is a positive impact on the growth of the economy in Dubai. The economy has benefited from adopting tourism by providing more employment opportunities, higher living standards, and noticeable economic empowerment. This growth was measured by the $\beta$ factor of the quality, assortment, and promotion of tourism service which were found at $0.114,0.117$, and 0.351 respectively. These findings suggested that all assumed hypotheses-related are positively supportive. The importance of these findings lies in constituting a solid foundation for the government of Dubai and the private sector to continue investing in the tourism sector hoping that the $\beta$ impact factor will be improved.
\end{abstract}

Index Terms - Tourism service quality, tourism service assortment, tourism promotion services living standards, economic empowerment, employment opportunities.

\section{INTRODUCTION}

The contemporary world is getting more complex, dynamic, globalized, and highly uncertain. Globalization, which is fostered and stimulated by a speedy change in ICT, is making the global economy more codependent. Globalization enables the free flow of skills, opportunities and investments among nations. It also results in higher efficiency, more effective products, more improved products and lower prices (Aigbogun, Ghazali, and Razali, 2014). In line with this, the tourism industry has become one of the largest, experienced, and the fastest growing industry. It has been reported that about $5 \%$ of GDP in 2011, and $6 \%-7 \%$ of

Prof Haj. Dr. Sadun N Yassin Alheety, Acadimic Consuultant,Faculity Of Finance and administrative Sciences, Al-Madinah International University

Tariq Khalaf Barakat Ayoub, Economic Department, Faculity Of Finance and administrative Sciences, Al-Madinah International University, Malaysia the total number of jobs globally (Benchabane, 2015). Given its size, the tourism industry bears substantial potential for economic growth, diversification, as well as the structural transformation of economies (Tan, Shi \& Niu, 2016).

Consequently, in recent times of increased competitive pressures, where numerous industry players are re-strategizing to survive the competition, it is vital that the impact of this industry be utilized in projecting economic growth due to its developmental impact on national economy.

Over the past decades, an increasing number of destinations have sprung up and invested in tourism development, making modern tourism a significant driver of socio-economic advancement via infrastructure development and revenue earning and by its closely connected to the food and beverage industries; construction industry, and entertainment industry. In the Gulf region where the Gulf Cooperation Council (GCC) nations are located, modern tourism has become the concern of governments and popular organizations. All GCC countries have begun to create national tourism development policies and have extremely expanded tourism through the adoption of positioning (re-positioning) plans for tourist destinations and niche tourism initiatives (Al-Hamarneh \& Stephenson, 2013).

In Dubai, the hospitality sector limited to restaurants and hotels accounted for 5\% of total GDP in 2013 compared to $4.6 \%$ in 2012 while others estimated it at 20-30\% (see Fig. 1) (Daghfous \& Barkhi, 2009). Moreover, Dubai has changed dramatically over the last three decades, becoming a key business center with a more dynamic and diversified economy for its strategic location (Stephens, 2008). Despite the nourishing tourism industry, there is a gap in the number and quality of journal papers that can shed light on the importance of this industry to the local economy.

\section{LITERATURE}

Tourism is among the fastest-growing industries in the world and, seemingly, it was not significantly affected during the recent worldwide economic crisis. Based on this perception, countries all over the world have become more dependent on tourism due to its stability. The aim of conducting a literature review is to ensure that no important variable from previous works that have been found repeatedly to have had an impact on the problem is ignored (Saunders et al. 2009).

Firstly and widely considered issues about tourism is that tourism is not only a source of income and employment; it goes way further as it seen in many life sectors as well as its effect on globalization the economic system and its cultural influence. Tourism has a "special function" in developing countries such as diversifying the economy, promotes high competitive fields, improves balance, utilizes investment, 
and balanced growth. In addition, tourism can generate huge business from small investment (Briedenhann \& Wickens, 2004). Tourism also contributes, at various levels, to improving education, smoothening governmental attitudes, creating professionalisms and increasing foreign currency exchange. Tourism is the most effective industry in creating diversified jobs and jobs opportunities. It also found that tourism is a powerful tool in preserving the historical places by creating the perception that these places are indeed a property for humanity.

The governments that are often creating wars and crises, find themselves in totally different position when it comes to tourism because, as noted many times, that tourism is a powerful tool for creating peace and goodwill (Akinboade \& Braimoh, 2010). Tourism is a field that countries are competing for each other rather than fighting each other. The comparative advantage for tourism can often aid developing nations in earning foreign exchange more rapidly and with less difficulty than would be true for other products (Getz \& Carlson, 2005). Nevertheless, problems are surfaced primarily due to a lack of coordination between tourism policy and environmental policy. Significant efforts are also devoted to conserving areas of natural beauty and maintaining resort areas and cultural communities.

The range of the impact of tourism on the economy starts at a moderate level to a high level. The impact also depends on the nature of the economic resources of the country. Countries that depend on agriculture, such as Caribbean countries, are very dependable on tourism while other countries are less (Mbaiwa, 2005). However, the general trend in all countries, regardless of their major revenue, is that they are trying to elevate the tourism industry to be the sustainable source of their revenue (Mbaiwa, 2005). Tourism has caused developing countries to lessen their reliance on traditional agricultural products for their main source of export earnings and has encouraged a diversification of their economies. As the need for foreign currency in the developing countries, tourism has lessened the hard or the impossible obstacle for obtaining foreign currency and, simultaneously, those countries have allowed very easy rules to deal with this issue (Dyer, Gursoy, Sharma \& Carter, 2007).

\section{A. Conceptual Framework and Hypothesis}

Research conceptual framework is the key to the entire research study by setting the required parameters and their relevant dependent and independent variables. It is a framework that helps a researcher to develop a logical opinion or theory of the relationship between different constructs and to set a proper set oh hypotheses. The independent variable comprises of input factors of tourism development which belong to the tourism service in quality, assortment, and promotion. The dependent variable is the economic growth which is composed of economic empowerment, living standards, and employment opportunities as shown in Fig. 1.

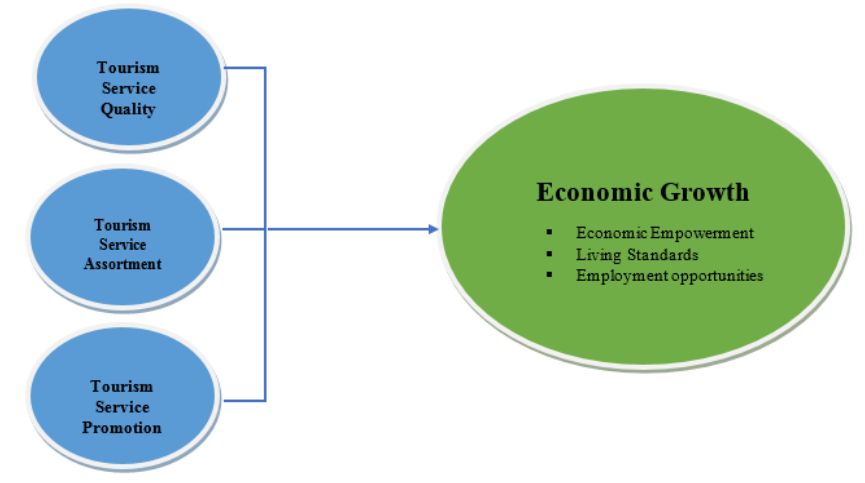

Fig. 1. The conceptual framework of tourism and economy growth

The following hypotheses are to be tested in this study:

H1: The tourism service quality and economic growth in Dubai are strongly related.

$\mathrm{H} 2$ : The tourism service assortment and economic growth in Dubai are strongly related.

H3: The tourism service promotion and economic growth in Dubai are strongly related

\section{Methodology}

The research aims at studying the independent and dependent variables by using a correlation technique to show how these variables are related. The study does not examine the complex cause and effect relationships between variables as this falls beyond the scope of this study and may be a topic for further research (Zikmund 2003). The extent of study interference was minimal because the data was collected through a survey. This required the researcher to be directly in touch with the candidates of the survey and the flow of work in the workplace continued as normal. The research philosophy applied in the study is positivism because a positivist approach allows for the quantification of data and for use of statistical analysis. The data was gathered through a survey which yielded quantitative information that was then summarized through statistical analyses (Zikmund, 2003). The study objective seeks to examine the Dubai citizens/permanent residents' perception of the impact of the development of tourism on national economic growth judging from their personal economic indices (economic empowerment, living standards, and employment opportunities). For this reason, the research is interested in the individual and their perceptions, and therefore the unit of analysis is the individual.

The research population was selected using nonprobability purposive and convenience sampling method in order to infer statistically valid generalizations about a particular characteristic of the research population. Purposive sampling involves the selection of respondents who are citizens or permanent residents of Dubai and also employed within the tourism sector. Reasons for the choice of this sampling technique were due to resource and time constraints. The samples were selected because they were easily accessible to the researcher (Saunders et al., 2009 and Zikmund, 2003). As a result, a cross-sectional research design was chosen to provide a 'snapshot' of the Dubai citizens/residents' perception level regarding the subject 
World Journal of Research and Review (WJRR)

ISSN:2455-3956, Volume-7, Issue-5, November 2018 Pages 06-09

matter - tourism developmental impact on economic growth.

\section{Research instrument}

The questionnaire of three sections $\mathrm{A}, \mathrm{B}$, and $\mathrm{C}$ comprised of closed-ended structured items for easy coding and analysis. Section A is designed as a nominal scale for 'Gender', 'Education level' Tourism industry type, and 'Residency status.' While Interval scale was used for 'Age'. Sections B is divided into 3 subsections of the Independent variables (Tourism service quality, Tourism service assortment, and Tourism service promotion). Each subsection is an input factor of Tourism development. The responses were anchored on the Likert scale that is, 1 for strongly disagree; 2 for disagree; 3 for neutral; 4 for agree and 5 for strongly agree. Section $\mathrm{C}$ was subdivided into 3 subsections of the different dimensions of the Dependent variable (Economic empowerment, Living standards, and Employment opportunities). The responses were anchored on the Likert scale of the basis of ranges which includes having numeric values represent a statement.

The questionnaire scales used in this research have been adopted from established scales from previous research and then adapted to fit the present study context. The scales for Economic growth from tourism development was adopted from Gartner, (2008); the scales for Tourist service quality was adopted from Feng Jr \& Zhang Jr, (2009); the scales for Tourist sales promotion was adopted from Leuschner (2010); and the scales for Tourists service assortment was adopted from Aspfors (2007). A reliability test conducted on the measurement scales in the present research revealed that the Cronbach alpha reliability values were all above the conventionally accepted value of 0.7 .

\section{DATA ANALYSIS AND INTERPRETATION}

\section{A. Data Management}

The data collected were subjected to screening and cleaning procedures. In Section A, the missing data were excluded further data analysis, making 404 questionnaires available for analysis out of the initial 407. In section B and section $\mathrm{C}$, the missing data were managed by replacing the missing values using SPSS 21.0. This was done by using the median replacement method.

\section{B. Descriptive Characteristics of Survey Participants}

Out of the total number of survey participants $(\mathrm{N}=404)$, it can be noted that there were by far more males $(68.3 \%)$ than females $(31.7 \%)$ that took part in the survey. As regards the age distribution of the survey participants, the largest percentage fall into the age group of 30-39 (34.4\%). In terms of the educational qualification, the largest percentage (74.5\%) possess a bachelor's degree or equivalent to their minimum level of educational qualification. As regards tourism industry type, the largest percentage of the survey respondents are engaged in the food and beverage industry $(26.5 \%)$. While, $77.5 \%$ of the survey participants are either citizens or holders of Dubai permanent residency permit, while the others $(22.5 \%)$ do not possess this, and may be residing in the city based on a work visa or otherwise. Table 1 is a summary of the demographic characteristics of the survey participants.
Table 1: Overview of demographic characteristic of the survey participants

\begin{tabular}{|c|c|c|c|}
\hline $\begin{array}{l}\text { Demographic } \\
\text { Characteristics }\end{array}$ & Category & Frequency & Percent \\
\hline \multirow{2}{*}{ Gender } & Male & 276 & 68.3 \\
\hline & Female & 128 & 31.7 \\
\hline \multirow{6}{*}{ Age } & Total & 404 & 100 \\
\hline & $\begin{array}{c}\text { Less than } 20 \\
\text { years }\end{array}$ & 56 & 13.9 \\
\hline & 20-29 years & 86 & 21.3 \\
\hline & 30-39 years & 139 & 34.4 \\
\hline & 40-49 years & 87 & 21.5 \\
\hline & $\begin{array}{l}50 \text { years and } \\
\text { above }\end{array}$ & 36 & 8.9 \\
\hline \multirow{5}{*}{$\begin{array}{l}\text { Educational } \\
\text { qualification }\end{array}$} & Total & 404 & 100 \\
\hline & $\begin{array}{c}\text { Secondary } \\
\text { school }\end{array}$ & 2 & 0.5 \\
\hline & Diploma & 29 & 7.2 \\
\hline & $\begin{array}{l}\text { Bachelor's } \\
\text { degree and } \\
\text { equivalent }\end{array}$ & 301 & 74.5 \\
\hline & $\begin{array}{l}\text { Post graduate } \\
\text { degree }\end{array}$ & 72 & 17.8 \\
\hline \multirow{8}{*}{$\begin{array}{l}\text { Tourism } \\
\text { industry }\end{array}$} & Total & 404 & 100 \\
\hline & Accommodation & 37 & 9.2 \\
\hline & $\begin{array}{l}\text { Food and } \\
\text { Beverage }\end{array}$ & 107 & 26.5 \\
\hline & Tour guide & 53 & 13.1 \\
\hline & Artisan/Caver & 29 & 7.2 \\
\hline & Transportation & 89 & 22 \\
\hline & Indirect service & 93 & 23 \\
\hline & Total & 404 & 100 \\
\hline \multirow{3}{*}{$\begin{array}{l}\text { Dubai } \\
\text { residency } \\
\text { status }\end{array}$} & Yes & 313 & 77.5 \\
\hline & No & 91 & 22.5 \\
\hline & Total & 404 & 100 \\
\hline
\end{tabular}

\section{Multiple Regression Analysis}

The main inferential statistical test employed in this research was the multiple regression analysis. Hence the survey data gathered from the respondents were subjected to the multiple regression model, in order to test the research hypotheses. Multiple regression analysis is used to predict the value of a variable based on the value of two or more other variables. In the present research, the following assumptions of multiple regression were fulfilled: sample size, screening for outliers, the normality of data distribution, test for correlation and multicollinearity.

For this research, there are 4 research variables made up of 3 independent variables (Tourism service quality, tourism service promotion, and tourism service assortment), and 1 dependent variable (Economic growth) study. Thus, a minimum of $60(4 \times 15)$ survey respondents is required. Going by this recommendation of sample size participants per predictor variable, it is noted that this research meets this vital assumption due to the fact that data was drawn from 404 survey participants (Pallant, 2013). Standardized residuals (ri) was utilized in the screening of outliers in this research. From the results gotten, all the standardized residuals were within the threshold of \pm 3.29 , except one case which was subjected to the Cook's distance, and the value of the Cook's distance was 0.169 , which is less than the recommended threshold of 1.0. Shapiro Wilk's test was used to test for normality of data distribution. For all the 
constructs, the significant value was greater than 0.05 so the null hypothesis that the data come from a normallydistributed population is accepted. In testing for multicollinearity, the tolerance values were all above 0.1 , therefore it is inferred that there was no multicollinearity amongst the independent variables.

In the Multiple Regression Analysis (Table 2) the Tourism development factors were treated as the predictor variables and the Economic growth dimensions as the dependent variables. Tourism development factors was a significant predictor of job satisfaction, $\mathrm{F}(45.431, p<$ $0.05), R^{2}=0.512$. Hence, Tourism development factors explain $51.2 \%$ of the variance in economic growth.

Table 2: Multiple regression analysis of communication and job satisfaction dimensions

\begin{tabular}{|c|c|c|c|c|}
\hline Variable & $R^{2}$ & F & $\begin{array}{c}\text { Beta } \\
(\beta)\end{array}$ & $\rho$ \\
\hline $\begin{array}{l}\text { Tourism service } \\
\text { quality }\end{array}$ & & & 0.114 & 0.041 \\
\hline $\begin{array}{l}\text { Tourism service } \\
\text { assortment }\end{array}$ & 0.512 & 45.431 & 0.117 & 0.038 \\
\hline $\begin{array}{l}\text { Tourism service } \\
\text { promotion }\end{array}$ & & & 0.351 & 0.000 \\
\hline
\end{tabular}

As observed in Table 2, the tourism development factors was also a significant predictor $(p<0.05)$ for economic growth in Dubai. Tourism service promotion had the strongest impact on economic growth $(\beta=0.351, p<0.05)$, followed by Tourism service assortment $(\beta=0.117, p<$ $0.05)$ and Tourism service quality $(\beta=0.114, p<0.05)$. As a result, all the three hypotheses are supported. Table 3 is a summary of the research hypotheses testing.

Table 3: Summary of Results of Hypotheses Testing

\begin{tabular}{|c|c|c|c|}
\hline $\begin{array}{l}\mathrm{H} \\
\mathrm{A} \\
\end{array}$ & Research Hypotheses & $\begin{array}{l}\text { Method of } \\
\text { testing }\end{array}$ & Results \\
\hline $\begin{array}{l}\mathrm{H} \\
1\end{array}$ & $\begin{array}{l}\text { The tourism service quality } \\
\text { and economic growth in } \\
\text { Dubai are strongly related. } \\
\text { The tourism service }\end{array}$ & $\begin{array}{l}\text { Multiple } \\
\text { regression }\end{array}$ & Supported \\
\hline $\begin{array}{l}\mathrm{H} \\
2\end{array}$ & $\begin{array}{l}\text { assortment and economic } \\
\text { growth in Dubai are } \\
\text { strongly related. }\end{array}$ & $\begin{array}{l}\text { Multiple } \\
\text { regression }\end{array}$ & Supported \\
\hline $\begin{array}{l}\mathrm{H} \\
3\end{array}$ & $\begin{array}{l}\text { The tourism service } \\
\text { promotion and economic } \\
\text { growth in Dubai are } \\
\text { strongly related. }\end{array}$ & $\begin{array}{l}\text { Multiple } \\
\text { regression }\end{array}$ & Supported \\
\hline
\end{tabular}

\section{CONCLUSION}

As a developing phenomenon that deserved investigation is the shift in Dubai to become one of the highest standards countries in providing tourists with all possible services while, simultaneously, keep monitoring the growth of the national economy. The feeling in Dubai that diversifying the revenues is the main mechanism for achieving better economic stability which reflects on social stability. This study is an attempt to investigate the contribution of the tourism sector to the national economy of Dubai. By setting the conceptual model, both variables, dependent and independent, were explored and studied using quantitative analysis as a questionnaire surveyed to more than 400 respondents. The quality, assortment, and promotion of tourism service were chosen as independent variables while the economic growth is the dependent variable. The findings have shown that there is a positive impact on the growth of the economy in Dubai. The economy has benefited from adopting tourism by providing more employment opportunities, higher living standards, and noticeable economic empowerment. It was found that the impact measured by the $\beta$ factor of the quality, assortment, and promotion of tourism service are $0.114,0.117$, and 0.351 respectively. These findings suggested all assumed hypotheses-related are positively supportive. These findings are very important and constitute a solid foundation for the government of Dubai and the private sector to continue investing in the tourism sector hoping that the $\beta$ impact factor will be improved.

\section{REFERENCES}

[1] Aigbogun, O., Ghazali, Z., \& Razali, R. (2014). A Framework to Enhance Supply Chain Resilience: The case of Malaysian Pharmaceutical Industry. Global Business and Management Research: An International Journal, 6(3): 219-229.

[2] Akinboade, O. A., \& Braimoh, L. A. (2010). International tourism and economic development in South Africa: A Granger causality test. International Journal of Tourism Research, 12(2), 149-163.

[3] Al-Hamarneh, A.; Stephenson, N. (2013). International Tourism Development in the GCC: Opportunities and Challenges; Gulf Research Center: Cambridge, UK.

[4] Aspfors, E. (2010). Customer perception of service, store image and product assortment: from an interior store perspective.

[5] Benchabane, Y. (20015). The Key Factors of a Sustainable and Successful Tourism Sector, The Case of Dubai. www.adademia.eu. [Assessed 13th July, 2016].

[6] Briedenhann, J., \& Wickens, E. (2004). Tourism routes as a tool for the economic development of rural areas — vibrant hope or impossible dream?. Tourism management, 25(1), 71-79.

[7] Daghfous, A., \& Barkhi, R. (2009). The strategic management of information technology in UAE hotels: An exploratory study of TQM, SCM, and CRM implementations. Technovation, 29(9), 588595.

[8] Dyer, P., Gursoy, D., Sharma, B., \& Carter, J. (2007). Structural modeling of resident perceptions of tourism and associated development on the Sunshine Coast, Australia. Tourism Management, 28(2), 409-422.

[9] Feng Jr, Y., \& Zhang Jr, X. (2009). The impact of customer relationship marketing tactics on customer loyalty within Swedish mobile telecommunication industry.

[10] Gartner, C. (2008). Tourism, Development, and Poverty Reduction: A Case Study from Nkhata Bay, Malawi. Thesis. University of Waterloo.

[11] Getz, D., \& Carlsen, J. (2005). Family business in tourism: state of the art. Annals of tourism research, 32(1), 237-258.

[12] Leuschner, R. (2010). The Impact of Product, Price, Promotion and Place/Logistics on Customer Satisfaction and Share of Business (Doctoral dissertation, The Ohio State University).

[13] Mbaiwa, J. E. (2005). Enclave tourism and its socio-economic impacts in the Okavango Delta, Botswana. Tourism Management, 26(2), 157-172.

[14] Pallant, J. (2007), SPSS survival manual. 5th ed. Buckingham: Open University Press.

[15] Saunders, M., Philip, L., and Adrian, T., (2009). Research Methods for Business Students, 5th ed. (Edinburgh: Ess: Pearson Education Ltd., 2009), p. 61.

[16] Tan, Y., Shi, Y., \& Niu, B. (Eds.). (2016). Advances in Swarm Intelligence: 7th International Conference, ICSI 2016, Bali, Indonesia, June 25-30, 2016, Proceedings (Vol. 9712). Springer.

[17] Wilson, S., Fesenmaier, D. R., Fesenmaier, J., \& Van Es, J. C. (2001). Factors for success in rural tourism development. Journal of Travel research, 40(2), 132-138. 